\title{
Field based speciation of arsenic in UK and Argentinean water samples
}

M.J. Watts ${ }^{1}$, J. O’Reilly ${ }^{1,2}$, A. L. Marcilla ${ }^{2}$, R. A. Shaw ${ }^{1}$ and N.I. Ward ${ }^{2}$

1. British Geological Survey, Keyworth Nottingham, UK. NG12 5GG mwatts@bgs.ac.uk

2. University of Surrey, Chemical Sciences, Faculty of Health and Medical Sciences, Guildford, UK, GU2 7XH. n.ward@surrey.ac.uk

\section{Abstract}

A field method is reported for the speciation of arsenic in water samples that is simple, rapid, safe to use beyond laboratory environments and cost effective. The method utilises solid phase extraction cartridges (SPE) in series for selective retention of arsenic species, followed by elution and measurement of eluted fractions by inductively coupled plasma mass spectrometry (ICP-MS) for 'total' arsenic. The method is suitable for on-site separation and preservation of arsenic species from water. Mean percentage accuracies $(\mathrm{n}=25)$ for synthetic solutions containing $10 \mu \mathrm{gl}^{-}$ 1 As of arsenite $\left(\mathrm{As}^{\mathrm{III}}\right)$, arsenate $\left(\mathrm{As}^{\mathrm{V}}\right)$, monomethylarsonic acid (MA) and dimethylarsinic acid (DMA), were $98 \%, 101 \%, 94 \%$ and $105 \%$, respectively. Data are presented to demonstrate the influence of $\mathrm{pH}$ and competing anions on the retention of the arsenic species. The cartridges were tested in the UK and Argentina at sites where arsenic was known to be present in surface and groundwaters respectively at elevated concentrations and in challenging matrix conditions. In Argentinean groundwater, 4 to $20 \%$ of speciated arsenic was present as MA and 20 to $73 \%$ as $\mathrm{As}^{\mathrm{III}}$. In UK surface waters, speciated arsenic was measured as 7 to $49 \%$ MA and 12 to $42 \%$ as DMA. Comparative data from the field method using SPE cartridges and laboratory method using liquid chromatography coupled to ICP-MS for all water samples provided a correlation of greater than 0.999 for $\mathrm{As}^{\mathrm{III}}$ and DMA, 0.991 for MA and 0.982 for $\mathrm{As}^{\mathrm{V}}(\mathrm{P}<0.01)$.

Keywords: Arsenic; field based speciation; solid phase extraction.

\section{$\underline{\text { Introduction }}$}

Arsenic has been documented to be ubiquitous in the environment in all regions of the world. There is an abundance of evidence for the toxicological effects of arsenic in drinking water (WHO, 2001; IARC, 2004; Rahman et al., 2009). The improvements 
in the ability to quantitatively measure arsenic and the concerns and greater understanding relating to exposure effects on human health led to the lowering of recommended and regulatory limits for arsenic in drinking water from 50 to $10 \mu \mathrm{g} \mathrm{l}^{-1}$ in 1993 (WHO, 1993). Human health effects due to arsenic toxicity are often characterised by skin lesions observed as melanosis and keratosis. Chronic arsenic exposure can have neurological, cardiovascular, respiratory effects, or cause skin, bladder and lung cancer (WHO, 2001; Karagas et al., 2002; Rahman et al., 2009).

Knowledge of the speciation of arsenic in natural water is important since the toxicity, mobility and adsorptivity of arsenic is dependent upon its chemical form. Redox conditions primarily govern the dissolved arsenic speciation, with inorganic arsenic being the dominant form. Monomethylarsonic acid (MA) and dimethylarsinic acid (DMA) have commonly been measured at lower levels in surface and groundwaters (Hwang and Jiang, 1994; Palacios et al., 1997; Roig-Navarro et al, 2001; Garbarino et al., 2002; IAEA, 2002; Bednar et al., 2002a; Bednar et al., 2004; Ronkart et al., 2007), rainwater and pore water (Huang and Ilgen, 2004). The severe health implications of high arsenic intake reported in West Bengal, Bangladesh, Taiwan and Inner Mongolia (Smedley et al., 2005) were mainly attributable to the high levels of inorganic arsenic in well water. Owing to the toxicity differences between arsenic species (As ${ }^{\mathrm{III}}>\mathrm{As}{ }^{\mathrm{V}}$ $>$ MA > DMA) (Francesconi and Kuehnelt, 2004) the speciation of arsenic is essential to improve the understanding of health implications and design processes to reduce the levels of arsenic present in drinking water.

The quantification of trace element species is a difficult task since trace elements are often present at low concentrations relative to the detection limits of analytical instrumentation. A number of methods have been employed and summarised in reviews of the scientific literature for arsenic speciation, such as spectroscopy, chromatography and electrochemical methods (Camel, 2003; Francesconi and Kuenhelt, 2004; Gonzalvez et al., 2009; Jain and Ali, 2000). Inductively coupled plasma mass spectrometry (ICP-MS) is often the favoured method for arsenic determination owing to its sensitivity and ability to couple to high performance liquid chromatography (HPLC) for the separation and measurement of arsenic species. $\mathrm{As}^{\mathrm{III}}, \mathrm{As}^{\mathrm{V}}, \mathrm{MA}$ and $\mathrm{DMA}$ can be measured routinely in solutions at low 
concentrations typically, low or sub- $\mu g 1^{-1}$ (Le et al., 1994; Feldmann et al., 1999; Polya et al., 2003; Watts et al., 2008; Button et al., 2009).

Changes in the distribution of arsenic species may occur rapidly after sampling, during storage and transport from the field to the laboratory, which would result in questionable speciation data (Hall et al., 1999). For example, changes in sample Eh or $\mathrm{pH}$ can precipitate $\mathrm{Al}, \mathrm{Fe}$ and $\mathrm{Mn}$ oxyhydroxides that adsorb arsenic species (Garbarino et al., 2002). Interconversion of $\mathrm{As}^{\mathrm{III}}$ and $\mathrm{As}^{\mathrm{V}}$ in water samples was noted by Le et al. (2000) and reported to be matrix dependent. Many studies have found that $\mathrm{As}^{\mathrm{V}}$, MA and DMA in surface waters are stable at below $4^{\circ} \mathrm{C}$ in the dark for between one day and several weeks depending on the water type, $\mathrm{pH}$ and matrix components. Species instability occurs mainly for $\mathrm{As}^{\mathrm{III}}$, which is readily oxidised to $\mathrm{As}^{\mathrm{V}}$ under certain conditions (Francesconi and Kuehnelt, 2004). Hydrochloric acid $(\mathrm{HCl})$ has been used for the preservation of $\mathrm{As}^{\mathrm{III}}$, with $\mathrm{As}^{\mathrm{V}}$ calculated from the subtraction of $\mathrm{As}^{\mathrm{III}}$ from total measurement. However, iron rich waters present a problem for arsenic species stability, since the ferric(oxyhydr)oxide phases that form from $\mathrm{Fe}(\mathrm{II})$ oxidation and $\mathrm{Fe}(\mathrm{III})$ hydrolysis can sorb arsenic from solution, changing the total concentration and likely the species distribution. The arsenic species can sorb to iron precipitates formed in unpreserved samples. Although McCleskey et al. (2004) have shown that $\mathrm{HCl}$ is an effective preservative for inorganic arsenic, acting as a biocide and inhibiting Fe(II) oxidation and Fe(III) hydrolysis, these findings are in contradiction to the work of Borho and Wilderer (1997). In addition, as with many other methods, this approach does not account for the presence of organoarsenicals. A number of procedures have been proposed to preserve the arsenic species in their 'natural' distribution. The addition of ethylenediaminetetraacetic acid (EDTA) (Bednar et al., 2002b; Huang and Ilgen, 2004) or phosphoric acid (Daus et al., 2002) to water samples has been used to minimise metal oxyhydroxide precipitation of arsenic species with Al, Fe and Mn. Gong et al. (2002) added ascorbic acid and HCl to synthetic water and maintained the concentration of $\mathrm{As}^{\mathrm{III}}, \mathrm{As}^{\mathrm{V}} \mathrm{MA}$ and DMA for 28 days, although transformation from $\mathrm{As}^{\mathrm{III}}$ to $\mathrm{As}^{\mathrm{V}}$ was observed within eight days for natural waters and three days for rainwater. Acidification with nitric acid $\left(\mathrm{HNO}_{3}\right)$ has also been proposed, but this approach would influence relative changes in inorganic $\mathrm{As}^{\mathrm{III}}$ and $\mathrm{As}^{\mathrm{V}}$ concentrations (Feldmann et al., 1999; Hall et al.; 1999, McCleskey et 
al., 2004). Gomez-Ariza et al. (2000) reviewed methods for arsenic species preservation, including freezing, cooling, acidification, addition of ascorbic acid and storage in the dark. There is generally no agreement in the literature on these procedures for on-site sample collection for laboratory speciation analysis, owing to the complexity and site-specific differences between water matrices (Leermakers et al., 2006).

Simple and inexpensive field kits have often been used to determine total arsenic rather than arsenic species, through the reduction of $\mathrm{As}^{\mathrm{III}}$ and $\mathrm{As}^{\mathrm{V}}$ to arsine gas $\left(\mathrm{AsH}_{3}\right)$ by $\mathrm{Zn}$ and $\mathrm{HCl}$ in a reaction vial (Kinniburgh and Kosmus, 2002). Generated arsine gas results in a colour change of a test strip containing mercuric bromide. Many commercially available kits are considered semi-quantitative below $100 \mu \mathrm{g}^{-1}$ and incapable of detecting arsenic concentrations close to the World Health Organisation (WHO) recommended limit of $10 \mu \mathrm{g}^{-1}$ for drinking water (Pande et al., 2001). Poor correlation between field kits employing arsine generation and laboratory-based measurements of 'total' arsenic are reportedly common (Hussam et al., 1999; Rahman et al., 2002; Arora et al., 2009). This method presents health and safety risks to the operator from the generation of arsine gas, of which up to $50 \%$ can escape from reaction cells (Hussam et al., 1999), handling of $\mathrm{HCl}$ in the field and resultant mercury solid wastes (Melamed, 2004) or oxalic acid when used for arsine generation (Baghel et al., 2007). Hydrochloric acid can be replaced with sulfamic acid for safer generation of arsine gas, whilst lead acetate filters are employed to reduce inherent sulphide interference prior to hydride generation (Cherukuri and Anjaneyulu, 2005).

Ficklin (1983) developed one of the earlier field methods for separating $\mathrm{As}^{\mathrm{V}}$ and $\mathrm{As}{ }^{\mathrm{III}}$ using ion exchange cartridges, although organoarsenicals were not separated from the $\mathrm{As}^{\mathrm{V}}$ fraction eluted from the cartridges. Edwards et al. (1998) modified the Ficklin method, using an anion exchange column to remove $\mathrm{As}^{\mathrm{V}}$, whilst $\mathrm{As}^{\mathrm{III}}$ was collected in the effluent $\left(\mathrm{As}^{\mathrm{V}}=\right.$ Total $\left.\mathrm{As}-\mathrm{As}{ }^{\mathrm{III}}\right)$. This approach assumed that no organic species were present in the water sample. Colloidal arsenic also provided a potentially false high result for $\mathrm{As}^{\mathrm{III}}$. Miller et al., (2000) also used a modified Ficklin method whereby samples were acidified with $0.12 \mathrm{M} \mathrm{HCl}$ and passed through an anion exchange resin (BioRad X-8, hydroxide form). Miller et al. (2000) demonstrated that 
particulate arsenic eluted from the resin with $\mathrm{As}^{\mathrm{III}}$, providing a false positive result. Therefore, a method was needed to separate and account for the organic species. Bednar et al. (2002b; 2005) and Garbarino et al. (2002) utilised anion exchange cartridges (Supelco, acetate form) by firstly preserving the water samples with EDTA and passing a known volume through the cartridges to successfully separate As ${ }^{\mathrm{III}}$ and $\mathrm{As}^{\mathrm{V}}$ species. Good comparisons were made for water samples analysed by field and laboratory methods, although neither of these studies could use the field speciation method if DMA or MA were present in the sample, since DMA and MA were retained on the cartridge with $\mathrm{As}^{\mathrm{V}}$ and required further separation. Le et al. (2000) solved this problem by using a resin-based cation exchange cartridge (Alltech) and an anion exchange cartridge (Supelco) in tandem to separate As ${ }^{\mathrm{III}}, \mathrm{As}^{\mathrm{V}}$, MA and DMA in synthetic solutions and surface waters, with subsequent analysis by Hydride Generation Atomic Absorption Spectrometry. The use of $\mathrm{HCl}$ to elute the arsenic species from the resin was not ideal for the determination of arsenic by ICP-MS owing to the formation of chloride polyatomic interferences $\left({ }^{40} \mathrm{Ar}^{35} \mathrm{Cl}^{+}\right)$and subsequent suppression of the ${ }^{75} \mathrm{As}^{+}$(100\% natural abundance) signal.

The use of solid phase extraction (SPE) ion exchange cartridges to overcome changes in the distribution of arsenic species after water sampling has been the focus of this study, particularly with respect to the geographical location of sampling sites in Argentina, where access to rapid and sensitive analyses was limited. A repetitive and safe method was required that could be used routinely in the field to immediately preserve arsenic species data and maintain the integrity of collected water samples until they could be returned to the UK for analysis.

\section{Study Sites}

\section{Devon Great Consols, UK}

The Devon Great Consols (DGC) is one of many former mining sites in South West England and is situated on the north east bank of the River Tamar in the Tavistock District of Devon (UK national grid reference SX: 426 735) (Figure 1a). Sites DGC 1 to 5 were collected along a stream from the north / topographic highpoint of the site (DGC 1) prior to it passing through arsenic sands (tailings) and DGC 2 to 5 through a series of ponds known locally as the 'arsenic ponds', before outflow into the River Tamar. DGC 6 to 9 were from drainage ditches at the south / topographical low-point 
of the site, intended to channel run-off from the main deposit of arsenic sands. DGC 10 was the outflow of algal rich water from an adit under the arsenic sands. DGC 11 and 12 were from pools of water on the surface of the main arsenic sand deposit. DGC 14 was collected from a drainage channel in pine woodland, with input from the adit outflow. DGC 13 and 15 were downstream of acid mine drainage (AMD) mixed into a stream entering the north / topographical high-point of the site and covered by mixed woodland. DGC was an ideal location for testing the field method since it had been studied extensively with respect to elemental composition of environmental samples and estimation of bioaccessibility. Arsenic concentrations in soils found in and around the mine varied significantly depending on their proximity to the main tailings, ranging from 249 to $34,000 \mathrm{mg} \mathrm{kg}^{-1}$ (Langdon et al., 2003; Klinck et al., 2005). Klinck et al. (2005) demonstrated the high potential for the release of arsenic from sulphide ore and other wastes by carrying out leaching experiments. This was confirmed by measurement of natural run-off showing elevated arsenic concentrations $\left(6577 \mu \mathrm{g}^{-1}\right)$. Arsenic concentrations of soils in the mine area and mine tailings were well above the $32 \mathrm{mg} \mathrm{kg}^{-1}$ soil guideline value (SGV) (EA, 2009) for gardens and allotments. Notably, bioaccessible concentrations of arsenic in soils were well above the SGV (up to $624 \mathrm{mg} \mathrm{kg}^{-1}$ ) (Button et al., 2008) in residential areas around the mine site, causing potential concern for human health.

\section{Argentina, South America}

The town of Ingeniero Luiggi (LU) (long. $64^{\circ} 28^{\prime} 60 \mathrm{~W}$, lat. $35^{\circ} 25^{\prime} 0 \mathrm{~S}$ ) situated in the north east of La Pampa Province in central Argentina provided a comparative test site for this study (Figures $1 \mathrm{~b} \& \mathrm{c}$ ). The region experiences semi-arid conditions with a temperate climate, with rainfall between 500 and $700 \mathrm{~mm}$ per year (Michelena and Irurtia, 1995). Naturally occurring high levels of arsenic have been reported in groundwaters in excess of $5300 \mu \mathrm{g} \mathrm{l}^{-1}$ (Smedley et al., 2005). Due to the lack of surface waters in north east La Pampa, groundwater sources are regularly used by the rural population for drinking, domestic and agricultural uses. Although groundwater is treated in Ingeniero Luiggi by reverse osmosis; it is sold in plastic containers rather than piped to households. Many properties, particularly remote farmsteads rely on the groundwater abstracted from boreholes without prior treatment. The untreated water was the focus of this study from town supply boreholes located in rural areas (LU 1 to 8) and rural farmsteads using private drinking supplies (LU 9 and 10), within $10 \mathrm{~km}$ 
of the town centre. The human health status of the rural communities in Argentina indicated typical arsenic poisoning related conditions, such as skin lesions, pigmentation changes and various forms of cancer.

\section{Materials and Methods}

Standards and Reagents

All chemicals were analytical reagent grade, with aqueous solutions prepared using deionised water (18.2 $\mathrm{M} \Omega$, Millipore, UK). Water samples $(30 \mathrm{ml})$ were filtered (0.45 $\mu \mathrm{m}$, Millex, UK) and preserved with $\mathrm{HNO}_{3}$ (BDH Aristar, UK) for total arsenic measurement. Commercial standards for $\mathrm{As}^{\mathrm{III}}$ in $2 \% \mathrm{HCl}, \mathrm{As}^{\mathrm{V}}$ in $2 \% \mathrm{NaOH} /$ trace bromine were obtained at $1000 \mathrm{mg} \mathrm{l}^{-1}$ (Fisher Scientific, UK), DMA (solid) (Greyhound Chromatography, UK) and MA (solid) (Sigma-Aldrich, UK) were used for arsenic species verification. Bromine, $\mathrm{F}, \mathrm{Cl}, \mathrm{Fe}, \mathrm{PO}_{4}, \mathrm{Mn}, \mathrm{NO}_{3}, \mathrm{NO}_{2}, \mathrm{SO}_{4}$ standards at $1000-10,000 \mathrm{mg}^{-1}$ (Sigma-Aldrich, UK) were used for matrix performance tests. Glacial acetic acid (Sigma-Aldrich, UK) and methanol (Fisher Scientific, UK) were used for the conditioning of the Bond Elut (SAX, SCX) ion exchange cartridges (Varian, UK).

\section{Methodology}

Preconditioning of the ion exchange cartridges was carried out in order to promote the adsorption of the arsenic species onto the appropriate SPE cartridges. Conditioning of the resin based strong cation exchange (SCX) cartridge used $15 \mathrm{ml}$ of $50 \%$ methanol followed by $15 \mathrm{ml}$ of $1 \mathrm{M}$ phosphoric acid and $5 \mathrm{ml}$ of deionised water (18.2 M $\Omega$ ). The strong anion exchange (SAX) cartridge was preconditioned with $15 \mathrm{ml}$ of $50 \%$ methanol and $5 \mathrm{ml}$ of deionised water. The flow rate used for preconditioning and loading of sample solution onto the cartridges was approximately 3 to $5 \mathrm{ml} \mathrm{min}^{-1}$. Following preconditioning, the cartridges were assembled as shown in Figure 2 and a measured volume of water sample (typically 20 to $30 \mathrm{ml}$ ) was passed through a 0.45 $\mu \mathrm{m}$ filter into a SCX cartridge connected in series to an SAX cartridge. The filter removed particulate arsenic, which has been reported to provide a false positive result for As ${ }^{\text {III }}$ (Edwards et al., 1998; Impelliterri, 2004). The SCX cartridge retained DMA, followed by the SAX cartridge, which retained $\mathrm{As}^{\mathrm{V}}$ and MA, whilst $\mathrm{As}{ }^{\mathrm{III}}$ was not retained and collected in the effluent in a polyethylene bottle. The filter and each of 
the cartridges were detached and stored in sealed polyethylene bags together with the polyethylene bottle containing the $\mathrm{As}^{\mathrm{III}}$ effluent and returned to the laboratory for analysis; elution of retained fractions and subsequent analysis for 'total' arsenic by ICP-MS. DMA was eluted from the SCX cartridge using $5 \mathrm{ml}$ of $1 \mathrm{M} \mathrm{HNO}_{3}$; MA eluted from the SAX cartridge using $5 \mathrm{ml}$ of $80 \mathrm{mM}$ acetic acid first, followed by $5 \mathrm{ml}$ of $1 \mathrm{M} \mathrm{HNO}_{3}$ to elute $\mathrm{As}^{\mathrm{V}}$. This concentration of acetic acid eluted MA up to $1 \mathrm{mg} \mathrm{l^{- }}$ ${ }^{1}$, whilst avoiding co-elution of $\mathrm{As}^{\mathrm{V}}$ with MA. Verification was obtained through secondary analyses of each fraction by HPLC-ICP-MS. Mean recoveries for MA in synthetic solutions were $105 \%$ and for $\mathrm{As}^{\mathrm{V}} 101 \%$. Figure 2 summarises the collection, separation and elution of arsenic species from the cartridges. All eluted fractions were diluted two-fold prior to analysis and determined for 'total' arsenic at m/z 75 using an Agilent 7500 ICP-MS instrument with matrix-matched calibration standards. For comparative speciation analysis by HPLC-ICP-MS, $30 \mathrm{ml}$ of filtered $(0.45 \mu \mathrm{m})$ water sample was stored in a light sealed Thermoelectric Cool box TC-14 (Waeco, UK) at $4^{\circ} \mathrm{C}$ for transport from the sampling site back to the laboratory. The cool box was powered from a car cigarette lighter socket. In addition, $30 \mathrm{ml}$ of filtered water was acidified to $1 \% \mathrm{HNO}_{3}(\mathrm{~F} / \mathrm{A})$ for total arsenic measurements. Instrumental conditions for total analysis by ICP-MS and arsenic speciation by HPLC-ICP-MS are described in Watts et al. (2007; 2008) and Button et al. (2009).

\section{Results and Discussion}

\section{Development of SPE methodology}

Bond Elut SAX and SCX ion exchange cartridges (Varian, UK) were used for the separation of arsenic species (As ${ }^{\mathrm{III}}, \mathrm{As}^{\mathrm{V}}, \mathrm{MA}, \mathrm{DMA}$ ) onto a solid phase. Bond Elut supplied SPE cartridges (Junior $500 \mathrm{mg}$ ) for direct attachment to syringe filters, which aided the separation under field conditions. Fractions collected for each arsenic species were subsequently checked by HPLC-ICP-MS (Watts et al., 2007; 2008) to confirm that individual species were present only in the expected fraction and that coelution had not occurred. Synthetic solutions containing $10 \mu \mathrm{g}^{-1} \mathrm{As}^{\mathrm{III}}, \mathrm{As}^{\mathrm{V}}, \mathrm{MA}$ and DMA were initially used to test the performance of the Bond Elut cartridges. After elution of the relevant species, and analysis by ICP-MS, arsenic recoveries for As ${ }^{\mathrm{III}}$, $\mathrm{As}^{\mathrm{V}}$, MA and DMA were $98 \%, 101 \%, 94 \%$ and $105 \%$, respectively $(\mathrm{n}=25)$ (Table 1). 
The SPE cartridges were intended for use in the field and so required a measure of robustness and reproducibility. Storage of the arsenic species on the SPE cartridges was tested by separating $10 \mathrm{ml}$ of solution containing $10 \mu \mathrm{g} \mathrm{l}^{-1}$ of each of the arsenic species onto the SPE. The SPEs were then stored in a sealed plastic bag at room temperature $\left(21^{\circ} \mathrm{C}\right)$ for one to four weeks avoiding direct sunlight. Recoveries of 100 $\pm 15 \%$ were obtained for each of the arsenic species after storage of the cartridges for four weeks. The SPEs provided good recoveries $(91-102 \%)$ for up to $10 \mathrm{mg} \mathrm{l}^{-1}$ of total arsenic (2.5 mg $1^{-1}$ of each arsenic species) with $30 \mathrm{ml}$ of this solution passed through the SPE. A $30 \mathrm{ml}$ volume of solution was considered the maximum to syringe through the SPE. This was mainly due to the practicalities in the field of the physical effort and time required to push $30 \mathrm{ml}$ of solution through the SPEs, but also to avoid saturating the SPEs in high matrix containing waters. A $30 \mathrm{ml}$ fraction of sample provided a 6-fold preconcentration (3-fold after dilution for total analysis) for $\mathrm{As}^{\mathrm{V}}, \mathrm{MA}$ and DMA.

The influence of $\mathrm{pH}$ on the recovery of arsenic species in spiked solutions of $10 \mu \mathrm{g}^{-1}$, at $\mathrm{pH}$ values of $4,6,8$ and 10 were tested in triplicate. The change in $\mathrm{pH}$ exhibited little effect on $\mathrm{As}^{\mathrm{III}}$ and DMA, with recoveries of 98 to $104 \%$ and 95 to $101 \%$, respectively. $\mathrm{As}^{\mathrm{V}}$ and MA exhibited slightly enhanced values of 109 to $114 \%$ and 111 to $117 \%$, respectively. None of the arsenic species showed any clear pattern with a change in $\mathrm{pH}$, and exhibited good reproducibility across the $\mathrm{pH}$ range tested.

The performance of the SPE cartridges was also tested using common matrix components found in water samples that challenged the ion exchange efficiency of the cartridges. These analytes were prepared as synthetic solutions with concentrations comparable to the elevated levels measured at the DGC site (Table 1) and spiked with individual arsenic species at $10 \mu \mathrm{g}^{-1}$ (in triplicate).

Mean concentrations for each arsenic species spiked with matrix components are summarised in Table 1. Recoveries were generally within $20 \%$ of the target value, with the exception of $25 \mathrm{mg}^{-1}$ fluoride and chloride, which inhibited the retention of MA (75 and $68 \%$ accuracy, respectively). At these levels of fluoride and chloride, the retention of MA on the SAX cartridge was reduced, whereas higher values were 
measured for $\mathrm{As}^{\mathrm{III} / \mathrm{V}}$ in the effluent from the SAX cartridge. Overall, the sum of arsenic species provided recoveries of 96 and $97 \%$ in the presence of chloride and fluoride, respectively. MA was also influenced by phosphate at concentrations of 1 $\mathrm{mg} \mathrm{l}^{-1}$ phosphate (79\% recovery), although enhanced values were measured in the $\mathrm{As}^{\mathrm{V}}(113 \%)$ eluted subsequently from the SAX cartridge. The reverse effect was observed for MA (113\%) and $\mathrm{As}^{\mathrm{V}}(79 \%)$ with $25 \mathrm{mg}^{-1}$ sulphate. Both sulphate and phosphate did not alter the $\mathrm{As}^{\mathrm{III}}$ concentration in the effluent, therefore $\mathrm{As}^{\mathrm{V}}$ and MA were retained on the SAX cartridge, but the elution of MA and $\mathrm{As}^{\mathrm{V}}$ were clearly influenced by the loading of these anions. Impelliterri (2004) also observed the reduction in mass balance ( $\Sigma$ species) when sulphate and phosphate were present as competing anions. Nitrate $\left(25 \mathrm{mg} \mathrm{l}^{-1}\right)$ did reduce the overall recovery of arsenic species, particularly MA and DMA, likely influencing the efficiency of the elution step, with MA (84\%) eluting subsequently with $\mathrm{As}^{\mathrm{V}}$ (110\%) and DMA (83\%) retained on the SCX cartridge.

Above the maximum for each matrix component presented in Table 1, a significant reduction in the individual arsenic species was seen. For example, nitrate at $100 \mathrm{mg} \mathrm{l}^{-}$ ${ }^{1}$ reduced all arsenic species to between $21-65 \%$. The increase in fluoride concentration (up to $45 \mathrm{mg} \mathrm{l}^{-1}$ ) showed a reduction in MA (48 to $59 \%$ ), and an increase in $\mathrm{As}^{\mathrm{III}}$ (115 to $133 \%$ ) recoveries. However, levels of DMA and $\mathrm{As}^{\mathrm{V}}$ remained relatively stable at $105 \%$ and $94 \%$ respectively. This pattern was also seen for the chloride matrix (50 to $200 \mathrm{mg} \mathrm{l}^{-1}$ ), with sum arsenic species recoveries in the range 93 to $101 \%$. Increases in sulphate (50 to $100 \mathrm{mg} \mathrm{l}^{-1}$ ), showed markedly reduced levels for MA (3 to $40 \%$ ) and significantly increased levels for As ${ }^{\text {III }}$ (134 to $167 \%$ ), but overall, the sum of all of the arsenic species gave total recoveries of 96 to $102 \%$, with altered distribution of arsenic species. Whilst knowledge of the matrix components is useful for interpreting the arsenic speciation data, it proved difficult to measure these components in the field in order to counter the problem of high matrix components prior to SPE separation / loading of the water sample. Therefore, the conductivity of each component and a mixed matrix solution was measured to define a limit for conductivity measurements. This provided an indication that if the conductivity of water samples measured in the field exceeded $1500 \mu \mathrm{S} \mathrm{cm}^{-1}$, then the water sample would require dilution with deionised water prior to passing the sample 
through the SPE to reduce the impact of matrix components on arsenic species recoveries, mainly through saturation of ion-exchange sites. Garbarino et al. (2002) recommended a dilution of $\mathrm{x} 10$ or more for samples with excessively high conductivity values to avoid interference from competing anions and cations. In practice, water samples with high conductivity values were diluted $\mathrm{x} 2$ prior to passing the sample through the SPE cartridges and x10 where conductivities were $>3999 \mu \mathrm{S}$ $\mathrm{cm}^{-1}$ for sites DGC 11, DGC 15, LU 6, LU 9 and LU 10 (Table 2).

\section{Devon Great Consols, UK}

Total arsenic concentrations measured in surface waters at the DGC site varied significantly depending on their proximity to the main tailings and in-flow of AMD. The total arsenic concentrations in filtered and acidified waters from the Devon Great Consols (DGC) were in the range 11 to $4592 \mu \mathrm{g} \mathrm{l^{-1 }}$, well above the $10 \mu \mathrm{g} \mathrm{l^{-1 }}$ recommended guideline for drinking water (WHO, 1993). Water samples were in general, slightly acidic at $\mathrm{pH} 3.5$ to 7.1 (Table 2). Anionic components were measured at concentrations of $<25 \mathrm{mg} \mathrm{l}^{-1}$ for chloride, sulphate and fluoride, $<0.4$ $\mathrm{mg}^{-1}$ for manganese and iron, $<0.1 \mathrm{mg}^{-1}$ for phosphate, bromide and nitrite, and $<$ $25 \mathrm{mg} \mathrm{l}^{-1}$ for nitrate, including samples diluted due to the on-site conductivity measurement exceeding $1500 \mu \mathrm{S} \mathrm{cm}^{-1}$. Exceptions were observed for sulphate in DGC $6\left(208 \mathrm{mg} \mathrm{l}^{-1}\right)$, DGC $7\left(85 \mathrm{mg} \mathrm{l}^{-1}\right)$, DGC 8 (260 mg $\left.\mathrm{m}^{-1}\right)$, DGC $11\left(332 \mathrm{mg} \mathrm{l}^{-1}\right)$, DGC $12\left(167 \mathrm{mg} \mathrm{l}^{-1}\right)$, DGC $13\left(73 \mathrm{mg} \mathrm{l}^{-1}\right)$ and DGC $15\left(104 \mathrm{mg} \mathrm{l}^{-1}\right)$.

Arsenic speciation using the SPE cartridges provided good accuracy (sum of arsenic species) compared to the total arsenic measurements (Table 2). The mean accuracy was $101 \pm 16 \%$. Table 2 shows that DMA and MA were present not just as minor constituents, but represented a significant proportion of the arsenic speciated for many of the water samples at the DGC site. MA and DMA accounted for 7 to $49 \%$ and 10 to $42 \%$, respectively, of the speciated arsenic. Many of the water sampling sites at the DGC were in close proximity to woodland areas, suggesting that a high level of organic content may be present in these samples or microbial activity may result in biotransformation of arsenic. The highest collective levels of DMA and MA were reported at DGC 1, 11, and 12. These three locations were contained within the more sandy surroundings of the acid mine tailings; however, algae was abundant along the watercourse, which may have contributed to the higher than expected levels of 
organic arsenic species. No other arsenic species were measured in DGC 1, 11 and 12 by HPLC-ICP-MS despite the presence of algae. Good comparative data were obtained by HPLC-ICP-MS for arsenic species (Table 3), with a correlation of 0.999 $(\mathrm{P}<0.01)$ for the sum of species, greater than 0.999 for $\mathrm{As}^{\mathrm{III}}$ and DMA, with $\mathrm{As}^{\mathrm{V}}$ and MA correlations of 0.980 and 0.989 , respectively. The poor agreement between methods for $\mathrm{MA}$ and $\mathrm{As}^{\mathrm{V}}$ at DGC 10 was likely due to a matrix component that affected the retention of $\mathrm{As}^{\mathrm{V}}$ and subsequent loss into the MA fraction. In general, matrix components were below the levels summarised in Table 1. Although conductivity was measured below $1500 \mu \mathrm{S} \mathrm{cm}^{-1}$ for DGC 10, an iron concentration of $1200 \mathrm{mg}^{-1}$ was measured on return to the laboratory. Removal of the DGC 10 datapoint provided a slight improvement in the correlation between methods to 0.985 and 0.999 for $\mathrm{As}^{\mathrm{V}}$ and MA, respectively for the combined dataset.

\section{Argentina}

Total arsenic concentrations in groundwaters from Ingeniero Luiggi (LU) were generally lower than from the DGC site, ranging from 133 to $305 \mu \mathrm{g} \mathrm{1^{-1 }}$, with a moderately alkaline $\mathrm{pH}$ of 7.4 to 8.4 (Table 2). High anion concentrations were also seen in LU waters for chloride and sulphate ranging from 48 to $1300 \mathrm{mg}^{-1}$ and 65 to $953 \mathrm{mg} \mathrm{l}^{-1}$, respectively. Arsenic species measured in these waters (Table 2) were mainly present as $A s^{I I I}$ or $A s^{V}$. No DMA was present, whilst MA was present as a minor constituent compared to the DGC waters, but nevertheless provided a significant contribution to the overall arsenic concentration in many of the waters. SPE data compared well with HPLC-ICP-MS, with correlations of 0.974, 0.965 and 0.986 for $\mathrm{As}^{\mathrm{III}}, \mathrm{As}^{\mathrm{V}}$ and MA, respectively $(\mathrm{P}<0.01)$. An outlier for sample LU 5 exhibited approximately $20 \%$ transformation from $\mathrm{As}^{\mathrm{III}}$ and $\mathrm{As}^{\mathrm{V}}$ in the filtered unacidified water (F/UA). When removed correlations improved to 0.999 and 0.976 for $\mathrm{As}^{\mathrm{III}}$ and $\mathrm{As}{ }^{\mathrm{V}}$, respectively.

The results of this research highlight the variation in toxic arsenic species present at both study locations. The toxicity of arsenic alters significantly depending upon the type of species, with $\mathrm{As}^{\mathrm{III}}>\mathrm{As}^{\mathrm{V}}>\mathrm{DMA}>\mathrm{MA}>\mathrm{AB}$ (Francesconi and Kuehnelt, 2004). Lower total arsenic was determined in the Argentinean (LU) groundwater samples (133 to $305 \mu \mathrm{g} \mathrm{l}^{-1}$ ) when compared to the DGC surface waters (11 to $4592 \mu \mathrm{g}$ 
$1^{-1}$ ); yet a significant proportion of arsenic resided as $\mathrm{As}^{\mathrm{III}}$ in the LU groundwater samples. The DGC surface waters contained a broader mix of arsenic species, including organoarsenicals. This is likely attributable to the waters being from different sources in the two study areas, namely groundwater in Argentina and surface water affected by AMD in the UK. The exposure route to humans differs between sites through the water usage. At the DGC site, drinking water is provided from offsite. However, through discussion with local residents, it appears that the LU waters on rural farmsteads are frequently used and often the only source of water for irrigation (crops and gardens), animal drinking water as well as human domestic use for drinking or cooking when treated water from the water treatment plant may be prohibitively expensive or inconvenient for regular use for some rural farmsteads

\section{Conclusions}

The SPE cartridges provided good quantitative recoveries for arsenic speciation of four arsenic species in water samples containing elevated concentrations of arsenic, although consideration of the water chemistry and presence of ionic matrix components was required to determine the distribution of arsenic species in water with confidence. A combined dataset for both the DGC and LU sites demonstrated a good linear correlation between the SPE and HPLC-ICP-MS methods at greater than 0.99 for $\mathrm{As}^{\mathrm{III}}$, DMA, MA and 0.98 for $\mathrm{As}^{\mathrm{V}}(\mathrm{P}<0.01)$ (Table 3, Figure 3a to d). Surface water samples from the DGC site in the UK contained a relatively high proportion of arsenic as organoarsenicals, the source likely to be from bacterial activity in iron and organic rich AMD waters, although further research is required to define the transformation process. MA contributed a relatively smaller proportion of the arsenic in Argentinean groundwaters, the source of which could also result from bacterial activity or from agricultural chemical applications as observed by Bednar et al (2002a) in the USA, in what is predominantly an agricultural region. The Argentinean groundwaters contained a significant proportion of arsenic as As ${ }^{\mathrm{III}}$. The identification of the distribution of arsenic and its chemical forms provides valuable information with regard to the toxicity, but also for the planning of remediation strategies for drinking and irrigation water through filtration, ion exchange or reverse osmosis that are cost effective and sustainable. 
The employment of the SPE cartridges in the field prevented changes in arsenic speciation that can occur between collection and analysis. This approach is necessary to reduce uncertainty due to the presence of matrix components, including iron, which reportedly promotes transformation from $\mathrm{As}^{\mathrm{III}}$ to $\mathrm{As}^{\mathrm{V}}$ even after preservation with $\mathrm{HCl}$ (Gong et al., 2002). This technology proved particularly practical in Argentina where sample collection was often in remote regions far from laboratories and enabled the preservation of arsenic species in the field through separation onto SPE cartridges, with subsequent elution and analysis back in the laboratory within a controlled timeframe. The availability of ICP-MS analytical facilities in Argentina is less widespread than in the UK. The preconcentration step provided by the cartridges allows the measurement of arsenic species at low levels (sub- $\mu \mathrm{g}^{-1}$ ) or even by more robust and less sensitive instrumentation, such as atomic absorption spectrometry, commonly used in developing countries. This method is a cost effective approach to arsenic speciation and proved simple to use under field conditions and robust in enabling reproducible arsenic speciation data for water samples.

\section{Acknowledgements}

The authors wish to thank project partners in Argentina, in particular Mr Adrian Fenocchio (Copeospil Ltda, Ingeniero Luiggi) for assistance in the collection of water samples in La Pampa and to the Tavistock Estate for access to the Devon Great Consols site. Thanks are also extended to Dr Simon Chenery for the checking of the manuscript. This paper is published with the permission of the Director of the British Geological Survey.

\section{References}

Arora, M., Megharaj, M. and Naidu, R. (2009). Arsenic testing field kits: some considerations and recommendations, Environmental Geochemistry Health, 31, 45 48.

Baghel, A., Singh, B., Pandey, P. and Sekhar, K. (2007). A rapid detection method for arsenic in drinking water, Analytical Science, 23, 135 - 137. 
Bednar, A.J., Garbarino, J.R., Ranville, J.F. and Wildeman, T.R. (2002a). Presence of organoarsenicals used in cotton production in agricultural water and soil of the southern United States, Journal of Agricultural Food Chemistry, 50, 7340 - 7344.

Bednar, A.J., Garbarino, J.R., Ranville, J.F. and Wildeman, T.R. (2002b). Preserving the distribution of inorganic arsenic species in groundwater and acid mine drainage samples, Environmental Science Technology, 36, 2213 - 2218.

Bednar, A.J., Garbarino, J.R., Burkhardt, M.R., Ranville, J.F. and Wildeman, T.R. (2004). Field and laboratory arsenic speciation methods and their application to natural water analysis, Water Research, 38, 355 - 364.

Bednar, A.J., Garbarino, J.R., Ranville, J.F. and Wildeman, T.R. (2005). Effects of iron on arsenic speciation and redox chemistry in acid mine water, Journal Geochemical Exploration, 85, 55 - 62.

Borho, M. and Wilderer, P. (1997). A reliable method for preservation and determination of arsenic(III) concentrations in groundwater and water works: Aqua, $46,138-143$.

Button, M., Watts, M.J., Cave, M.R., Harrington, C.F. and Jenkin, G.R.T. (2008). Earthworms and in vitro physiologically based extraction tests: complimentary tools for a holistic approach towards understanding risk at arsenic contaminated sites, Environmental Geochemistry Health, 31, 273 - 282.

Button, M., Jenkin, G.R.T., Harrington, C.F. and Watts, M.J. (2009). Human toenails as a biomarker of exposure to elevated environmental arsenic, Journal of Environmental Monitoring, 11, 610-617.

Camel, V. (2003). Solid phase extraction of trace elements, Spectrochimica Acta Part $B, 58,1177-1233$. 
Cherukuri, J. and Anjaneyulu, Y. (2005). Design and development of low cost, simple, rapid and safe, modified field kits for the visual detection and determination of arsenic in drinking water samples, International Journal Environmental Research Public Health, 2, 322 - 327.

Daus, B., Mattusch, J., Wennrich, R. and Weiss, H. (2002). Investigation on stability and preservation of arsenic species in iron rich water samples, Talanta, 58, $57-65$.

EA. (2009). Soil Guideline Values for inorganic arsenic in soil, Science Report SC050021/arsenic SGV, Environment Agency, Bristol. Available from: http://www.environment-

agency.gov.uk/static/documents/Research/SCHO0409BPVY-e-e.pdf $\quad$ [Accessed December 2009].

Edwards, M., Patel, S., McNeill, L., Chen, H-W., Frey, M., Eaton, A.D., Antweiler, R.C. and Howard, E. (1998). Considerations in As analysis and speciation, JAWWA, $90,103-113$.

Feldmann, J., Lai, V.W-M., Cullen, W.R., Ma, M., Lu, X. and Le, X.C. (1999). Sample preparation and storage can change arsenic speciation in human urine, Clinical Chemistry, 45, 1988 - 1997.

Ficklin, W.H. (1983). Separation of arsenic (III) and arsenic (V) in groundwaters by ion-exchange, Talanta, 30, $371-373$.

Francesconi, K.A. and Kuehnelt, D. (2004). Determination of arsenic species: a critical review of methods and applications, Analyst, 129, 373 - 395.

Garbarino, J.R., Bednar, A.J. and Burkhardt, M.R. (2002). Methods of analysis by the U.S. Geological Survey National Water Quality Laboratory - arsenic speciation in natural water samples using laboratory and field methods, U.S. Geological Survey Water Resources Investigations Report 02-4144. 
Gomez-Ariza, J.L., Morales, E., Sanchez-Rodas, D. and Giraldez, I. (2000). Stability of chemical species in environmental matrices, Trends in Analytical Chemistry, 19, $200-209$.

Gong, Z., Lu, X., Ma, M., Watt, C. and Le, X.C. (2002). Arsenic speciation analysis, Talanta, 58, $77-96$.

Gonzalvez, A., Cervera, M.L., Armenta, S. and de la Guardia, M. (2009). A review of non-chromatographic methods for speciation analysis, Analytica Chimica Acta, 636, $129-157$.

Hall, G.E.M., Pelchat, J.C. and Gauthier, G. (1999). Stability of inorganic arsenic (III) and arsenic (V) in water samples, Journal of Analytical Atomic Spectrometry, 14, 205 $-213$.

Huang, J-H. and Ilgen, G. (2004). Blank values, adsorption, preconcentration and sample preservation for arsenic speciation of environmental water samples, Analytica Chimica Acta, 512, 1 - 10.

Hussam, A., Alauddin, M., Khan, A.H., Rasul, S.B., and Munir, A.K.M. (1999).

Evaluation of arsine generation in arsenic field kit, Environmental Science Technology, 33, 3686-3688.

Hwang, C-J. and Jiang, S-J. (1994). Determination of arsenic compounds in water samples by liquid chromatography-inductively coupled plasma mass spectrometry with an in situ nebuliser-hydride generator, Analytica Chimica Acta, 289, 205 - 213.

IAEA (2002). International Atomic Energy Agency 2nd Research Co-ordination Meeting Report for the CRP on: "Development and Validation of Speciation Analysis using Nuclear Techniques”. International Atomic Energy Agency, Vienna.

IARC (2004). International Agency for Research on Cancer Monograph 84: Some drinking water disinfectants and contaminants including arsenic. World Health Organisation, Geneva. 
Impelliterri, C.A. (2004). Effects of $\mathrm{pH}$ and competing anions on the speciation of arsenic in fixed ionic strength solutions by solid phase extraction cartridges, Water Research, 38, 1207 - 1214.

Jain, C.K. and Ali, I. (2000). Arsenic: occurrence, toxicity and speciation techniques, Water Research, 34, $4304-4312$.

Karagas, M.R., Stukel, T.A. and Tosteson, T.D. (2002). Assessment of cancer risk and environmental levels of arsenic in New Hampshire, International Journal Hygiene Environmental Health, 205, 85 - 94.

Kinniburgh, D.G. and Kosmus, W. (2002). Arsenic contamination in groundwater: some analytical considerations, Talanta, 58, $165-180$.

Klinck, B.A., Palumbo, B., Cave, M.R. and Wragg, J. (2005). Arsenic dispersal and bioaccessibility in mine contaminated soils: a case study from an abandoned arsenic mine in Devon, UK. British Geological Survey Research Report RR/04/003.

Langdon, C.J., Piearce, T.G., Meharg, A.A. and Semple, K.T., (2003). Interactions between earthworms and arsenic in the soil environment: a review, Environmental Pollution, 124, 361-373.

Le, X.C., Cullen, W.R. and Reimer, K.J. (1994). Speciation of arsenic compounds by HPLC with hydride generation atomic spectrometry and inductively coupled plasma mass spectrometry detection, Talanta, 41, 495-502.

Le, X.C., Yalcin, S. and Mingsheng, M.A. (2000). Speciation of Submicrogram per liter levels of arsenic in water: on-site species separation integrated with sample collection, Environmental Science Technology, 34, 2342 - 2347.

Leermakers, M., Baeyens, W., De Gieter, M., Smedts, B., Meert, C., De Bisschop, H.C., Morabito, R. and Quevauviller, P. (2006). Toxic arsenic compounds in 
environmental samples: speciation and validation, Trends in Analytical Chemistry, 25, $1-10$.

McCleskey, R.B., Nordstrom, D.K. and Maest, A.S. (2004). Preservation of water samples for arsenic (III/V) determinations: an evaluation of the literature and new analytical results, Applied Geochemistry, 19, 995 - 1009.

Melamed, D. (2004). Monitoring arsenic in the environment: a review of science and technologies for field measurements and sensors, EPA 542/R-04/002, U.S. Environmental Protection Agency, Washington DC 20460.

Michelena, R.O. and Irurtia, C.B. (1995). Susceptibility of soil to wind erosion in La Pampa Province, Argentina, Arid Soil Research Rehabilitation, 9, 227 - 234.

Miller, G.P., Norman, D.I. and Frisch, P.L. (2000). A comment on arsenic species separation using ion exchange, Water Research, 34, 1397 - 1400.

Palacios, M.A., Gomez, M., Camara, C. and Lopez, M.A. (1997). Stability studies of arsenate, monomethylarsonate, dimethylarsinate, arsenobetaine, and arsenocholine in deionised water, urine and clean-up dry residue from urine samples and determination by liquid chromatography with microwave assisted oxidation-hydride generation atomic absorption spectrometric detection, Analytica Chimica Acta, 340, 209 - 220.

Pande, S.P., Deshpande, L.S. and Kaul, S.N. (2001). Laboratory and field assessment of arsenic testing field kits in Bangladesh and West Bengal, India, Environmental Monitoring Assessment, 68, 1 - 18.

Polya, D.A., Lythgoe, P.R., Abou-Shakra, F., Gault, A.G., Brydie, J.R., Webster, J.G., Brown, K.L., Nimfopoulos, M.K. and Michailidis, K.M. (2003). IC-IC-ICP-MS and IC-ICP-HEX-MS determination of arsenic speciation in surface and groundwaters: preservation and analytical issues, Mineralogical Magazine, 67, 247 - 261.

Rahman, M.M, Mukherjee, D., Sengputa, S.K., Chowdhury, U.K., Lodh, D.C., Roy, S., Selim, M., Quamruzzaman, Q., Milton, A.H., Shahidullah, S.M., Rahman, M.T. 
and Chakraborti, D. (2002). Effectiveness and reliability of arsenic field test kits: are the million dollar screening projects effective or not? Environmental Science Technologies, 36, 5385 - 5394.

Rahman, M.M., Ng, J.C. and Naidu, R. (2009). Chronic exposure of arsenic via drinking water and its adverse health impacts on humans, Environmental Geochemistry Health, 31, 189 - 200.

Roig-Navarro, A.F., Martinez-Bravo, Y., Lopez, F.J. and Fernandez, F. (2001). Simultaneous determination of arsenic species and chromium (VI) by high performance liquid chromatography-inductively coupled plasma mass spectrometry, Journal Chromatography A, 912, 319 - 327.

Ronkart, S.N., Laurent, V., Carbonelle, P., Mabon, N., Copin, A. and Barthelemy, JP. (2007). Speciation of five arsenic species (arsenite, arsenate, $\mathrm{MMAA}^{\mathrm{V}}, \mathrm{DMAA}^{\mathrm{V}}$ and AsBet) in different kind of water by HPLC-ICP-MS, Chemosphere, 66, 738 745.

Smedley, P.L., Kinniburgh, D.G., MacDonald, D.M.J., Nicolli, H.B., Barros, A.J., Tullio, J.O., Pearce, J.M. and Alonso, M.S. (2005). Arsenic associations in sediments from the loess aquifer of La Pampa, Argentina, Applied Geochemistry, 20, 989-1016.

Watts, M.J., O’Reilly, J., Smiles, C.A. and Cook, J.M. (2007). Measurement of Arsenic Compounds in Water by HPLC-ICP-MS. British Geological Survey Internal Technical Report, OR/07/021.

Watts, M.J., Button, M., Brewer, T.S., Jenkin, G.R.T. and Harrington, C.F. (2008). Quantitative arsenic speciation in two species of earthworms from a former mine site, Journal of Environmental Monitoring, 10, 753 - 759.

WHO. (1993). Arsenic in Drinking Water, World Health Organisation Factsheet 210. World Health Organisation, Geneva. 
WHO. (2001). International Programme on Chemical Safety Environmental Health Criteria 224: Arsenic and arsenic compounds. World Health Organisation, Geneva. 
Figures and Tables

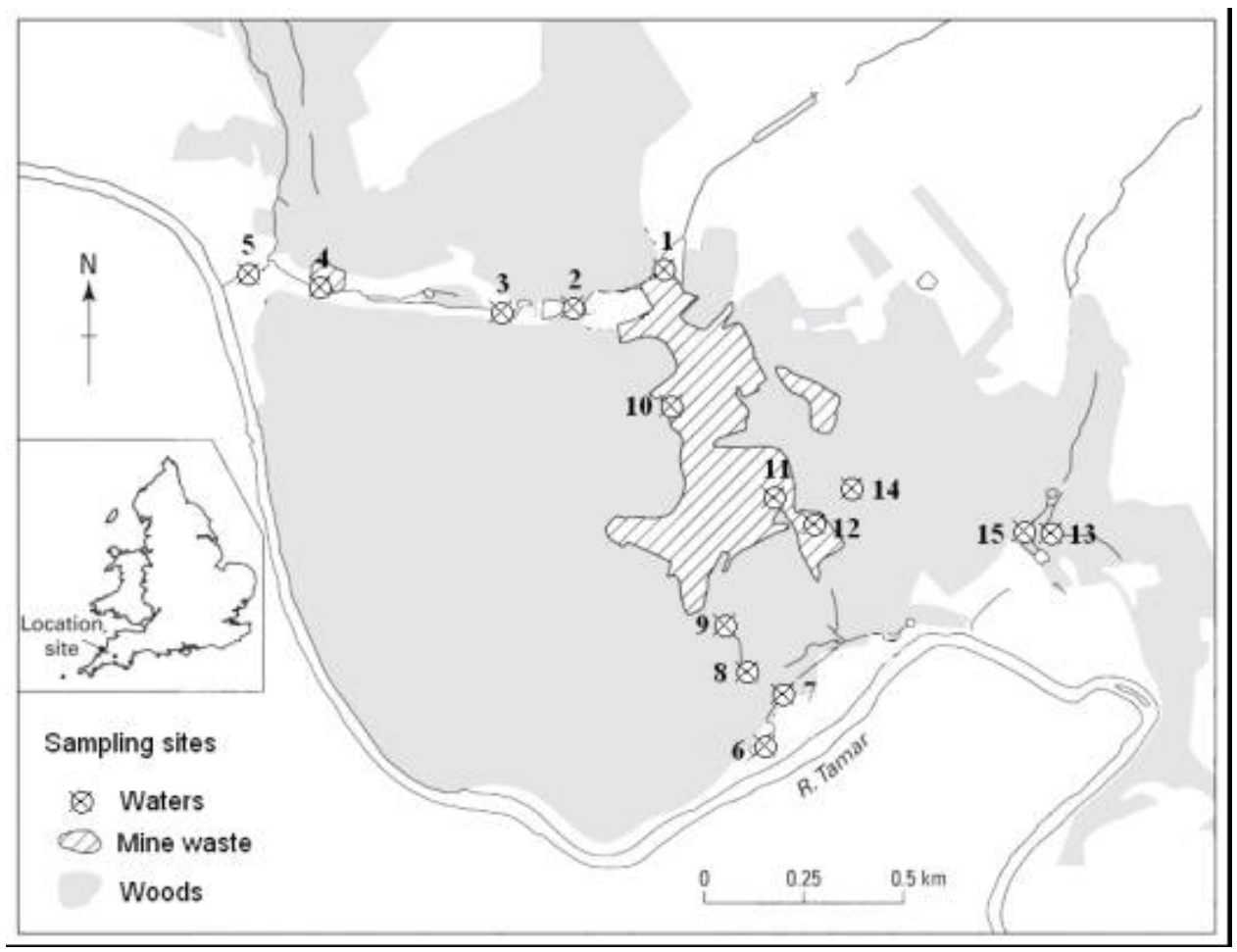

Figure 1a: Sampling location map for the Devon Great Consols, Tavistock District, Devon, UK (UK national grid reference SX: 426 735).

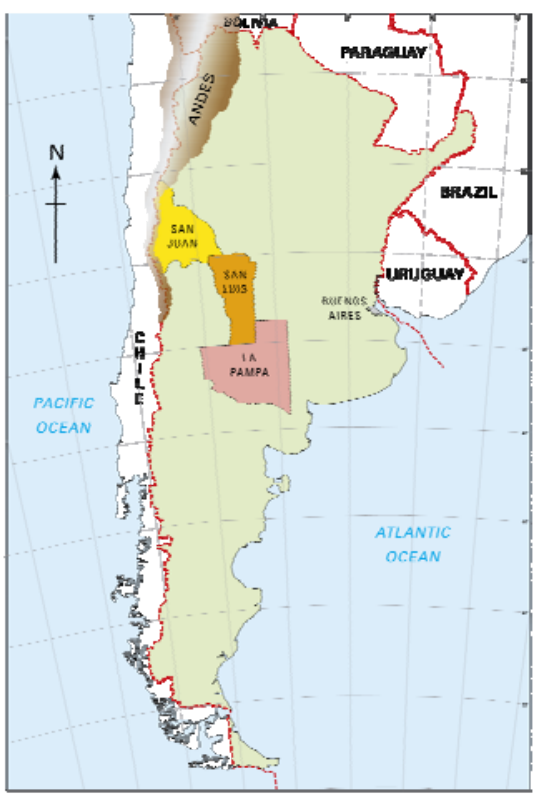

b)

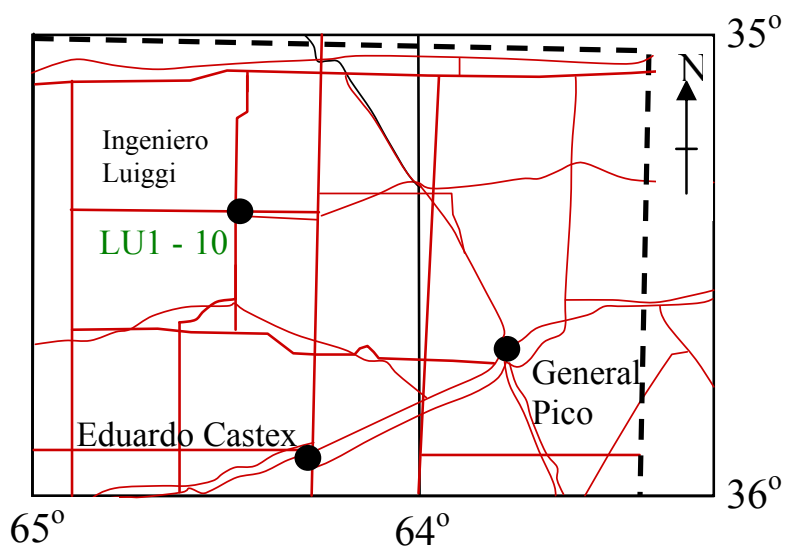

Key

- - Provincial border

- Road

Scale:

- Settlement

c)

Figures $1 \mathrm{~b}$ and $\mathrm{c}$ : Map of Argentina (b) to show the relative position of La Pampa province in Argentina. Sampling sites around Ingeniero Luiggi are shown (c); the town is situated in the north east of La Pampa province. Prepared courtesy of Mr Paul Lappage, British Geological Survey, 2008. 


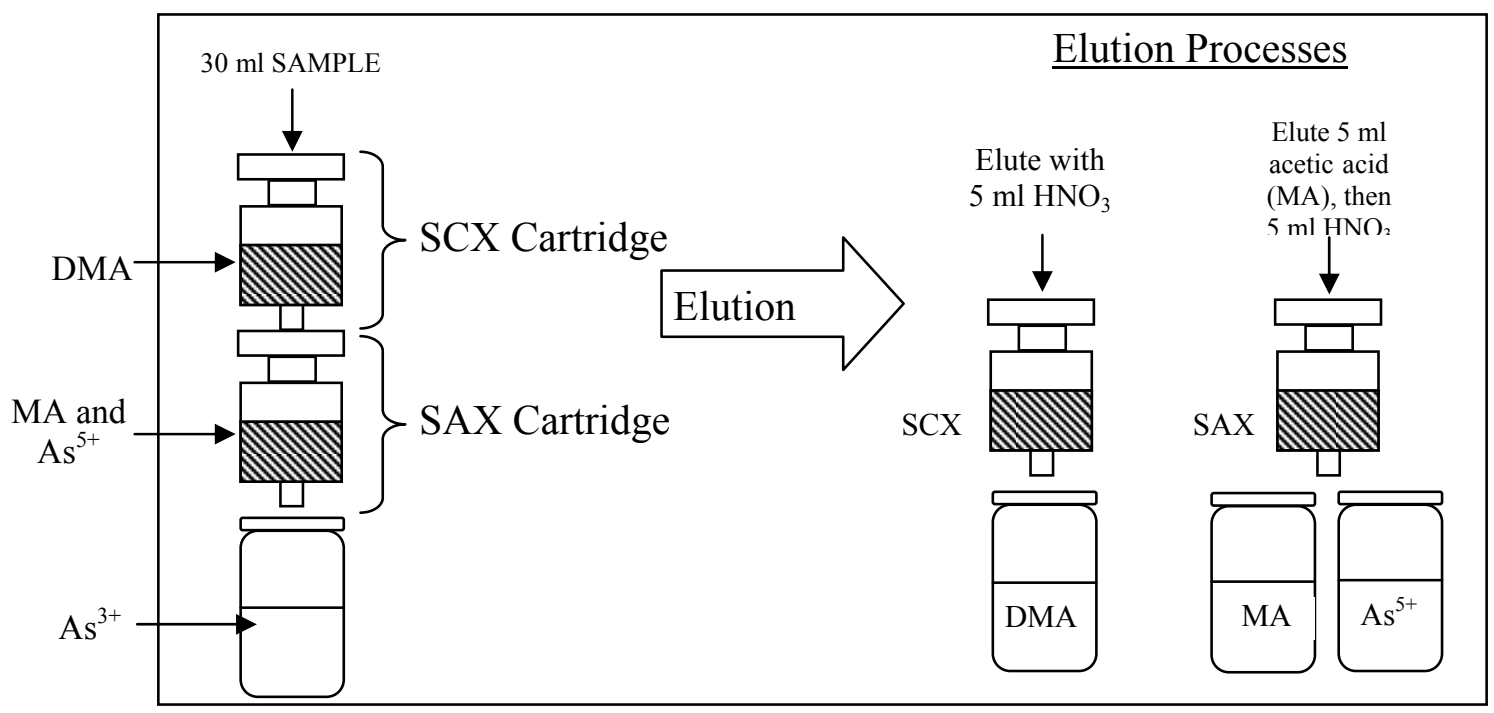

Figure 2: Schematic for the collection and separation of arsenic species in water samples and subsequent elution into separate fractions for analysis by ICP-MS. 

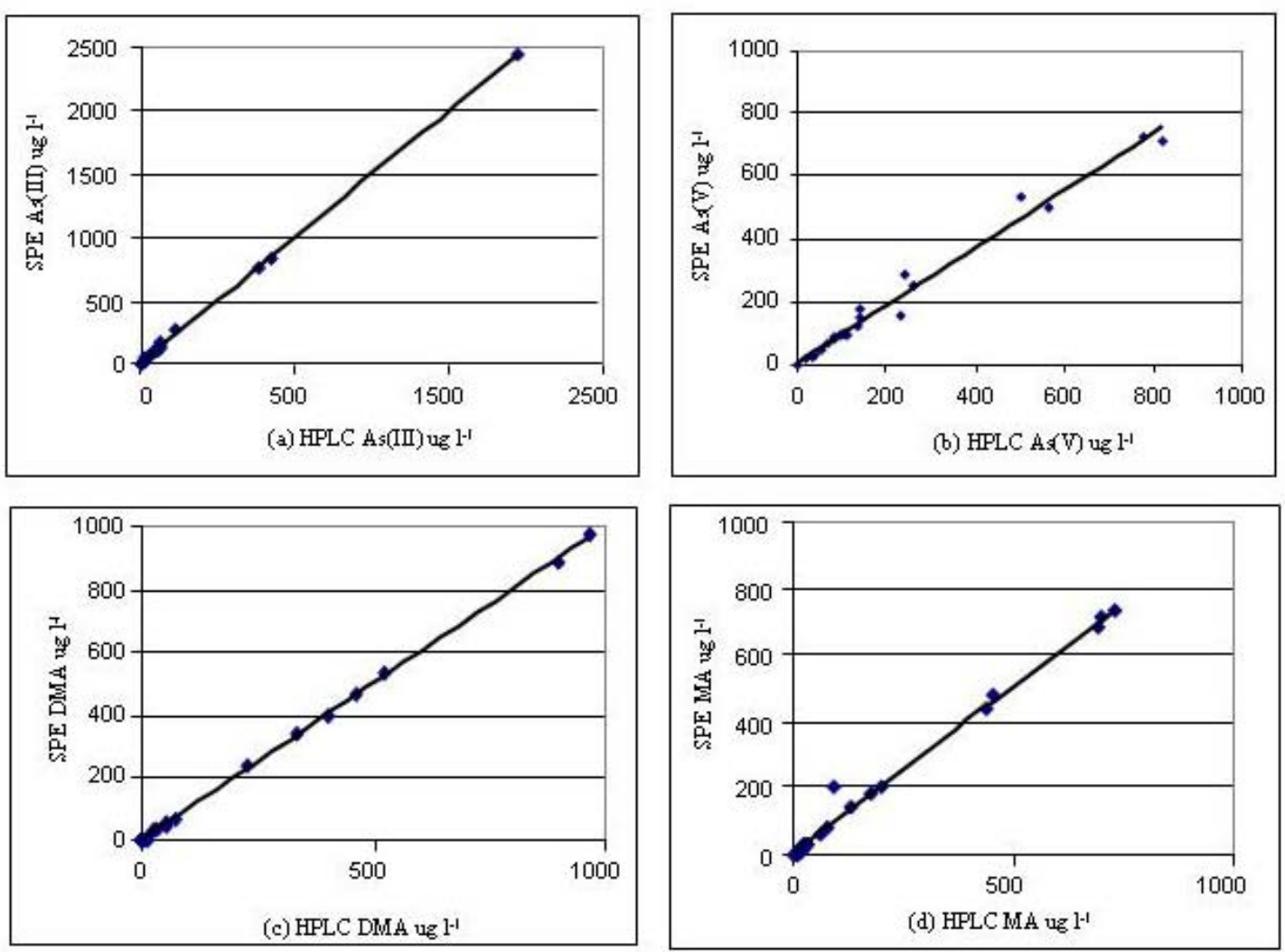

Figure 3: Comparison of As recoveries following analysis by HPLC-ICP-MS and SPE using regression plots for (a) $\mathrm{As}^{\mathrm{III}}$, (b) $\mathrm{As}^{\mathrm{V}}$, (c) DMA and (d) MA for both the DGC and LU sites $(\mathrm{n}=25)$. 
Table 1: Matrix influence on the SPE recovery.

\begin{tabular}{|c|c|c|c|c|c|c|}
\hline $\begin{array}{l}\text { Matrix } \\
\text { components }\end{array}$ & $\mathrm{As}^{\mathrm{III}}$ & $\begin{array}{l}\mathrm{As}^{\mathrm{V}} \\
\mathrm{Rec}\end{array}$ & $\begin{array}{l}\text { DMA } \\
y(\%)\end{array}$ & MA & Mean & $\mathrm{SD}$ \\
\hline Deionised water* & 98 & 101 & 105 & 94 & 100 & 4 \\
\hline $\mathrm{Fe} \quad 1.0 \mathrm{mg} \mathrm{l}^{-1}$ & 99 & 100 & 107 & 97 & 101 & 4 \\
\hline $\mathrm{Mn} \quad 0.4 \mathrm{mg} \mathrm{l}^{-1}$ & 109 & 97 & 117 & 91 & 104 & 12 \\
\hline $\mathrm{Cl} \quad 25 \mathrm{mg} \mathrm{l}^{-1}$ & 111 & 109 & 97 & 68 & 96 & 20 \\
\hline $\mathrm{F} \quad 25 \mathrm{mg} \mathrm{l}^{-1}$ & 110 & 109 & 92 & 75 & 97 & 17 \\
\hline $\mathrm{Br} \quad 1.0 \mathrm{mg} \mathrm{l}^{-1}$ & 105 & 101 & 95 & 81 & 96 & 11 \\
\hline $\mathrm{NO}_{3} 25 \mathrm{mg} \mathrm{l}^{-1}$ & 90 & 110 & 83 & 84 & 92 & 13 \\
\hline $\mathrm{NO}_{2} 1.0 \mathrm{mg} \mathrm{l}^{-1}$ & 104 & 107 & 94 & 84 & 97 & 10 \\
\hline $\mathrm{PO}_{4} 1.0 \mathrm{mg} \mathrm{l}^{-1}$ & 102 & 113 & 96 & 79 & 98 & 14 \\
\hline $\mathrm{SO}_{4} 25 \mathrm{mg} \mathrm{l}^{-1}$ & 101 & 79 & 93 & 113 & 97 & 14 \\
\hline
\end{tabular}

$30 \mathrm{ml}, 10 \mu \mathrm{g} \mathrm{l}^{-1}$ As, each species, $\mathrm{n}=3,{ }^{*} \mathrm{n}=25$ 
Table 2: Total arsenic - with SPE speciated arsenic represented as a percentage of the sum of arsenic species measured - and $\mathrm{pH}$ and conductivity results in Devon Great Consols (UK) and Argentinean waters.

\begin{tabular}{|c|c|c|c|c|c|c|c|c|c|}
\hline SITE & $\mathrm{pH}$ & $\begin{array}{c}\text { Conductivity } \\
\mu \mathrm{S} \mathrm{cm}\end{array}$ & $\begin{array}{c}\text { Total As } \\
\text { F/A* } \\
\mu g ~^{-1}\end{array}$ & $\begin{array}{c}\text { Sum As } \\
\text { Species } \mu g 1^{-1}\end{array}$ & $\begin{array}{c}\text { Recovery } \\
\%\end{array}$ & $\begin{array}{l}\mathrm{As}^{\mathrm{III}} \\
\%\end{array}$ & $\begin{array}{l}\mathrm{As}^{\mathrm{V}} \\
\mathrm{of} \mathrm{Sp}\end{array}$ & $\begin{array}{l}\mathrm{DMA} \\
\text { iated }\end{array}$ & $\begin{array}{l}\text { MA } \\
\text { enic }\end{array}$ \\
\hline \multicolumn{10}{|c|}{ DGC, UK - surface waters + AMD } \\
\hline 1 & 4.5 & 1773 & 1218 & 899 & 74 & 3 & 10 & 38 & 49 \\
\hline 2 & 7.0 & 1429 & 55 & 69 & 125 & 14 & 29 & 42 & 15 \\
\hline 3 & 7.1 & 1624 & 521 & 492 & 95 & 1 & 51 & 10 & 38 \\
\hline 4 & 6.5 & 2257 & 39 & 43 & 110 & 16 & 65 & 12 & 7 \\
\hline 5 & 7.3 & 1507 & 11 & 10 & 93 & 30 & 10 & 40 & 20 \\
\hline 6 & 4.6 & 1965 & 234 & 180 & 77 & 9 & 44 & 29 & 17 \\
\hline 7 & 5.6 & 1610 & 4592 & 4658 & 101 & 53 & 11 & 21 & 16 \\
\hline 8 & 5.1 & 1839 & 1687 & 1931 & 114 & 44 & 37 & 12 & 7 \\
\hline 9 & 5.5 & 1811 & 2785 & 2433 & 87 & 4 & 30 & 37 & 29 \\
\hline 10 & 5.6 & 1609 & 466 & 446 & 96 & 4 & 35 & 16 & 45 \\
\hline 11 & 3.6 & 3999 & 159 & 182 & 115 & 8 & 25 & 21 & 46 \\
\hline 12 & 5.6 & 2015 & 1152 & 1444 & 125 & 18 & 12 & 37 & 33 \\
\hline 13 & 5.4 & 1921 & 1791 & 1651 & 92 & 47 & 18 & 24 & 12 \\
\hline 14 & 4.4 & 2357 & 1800 & 1714 & 95 & 2 & 31 & 27 & 40 \\
\hline 15 & 3.5 & 3995 & 100 & 112 & 113 & 35 & 32 & 21 & 13 \\
\hline \multicolumn{10}{|c|}{ Ingeniero Luiggi, Argentina - groundwaters } \\
\hline 1 & 7.4 & 1264 & 231 & 232 & 100 & 45 & 43 & 0 & 12 \\
\hline 2 & 8.1 & 1015 & 182 & 169 & 93 & 25 & 57 & 0 & 17 \\
\hline 3 & 8.2 & 1215 & 305 & 302 & 99 & 31 & 50 & 0 & 20 \\
\hline 4 & 8.2 & 1267 & 156 & 162 & 104 & 23 & 58 & 0 & 19 \\
\hline 5 & 8.1 & 2888 & 293 & 295 & 101 & 55 & 41 & 0 & 4 \\
\hline 6 & 7.9 & $>3999$ & 167 & 167 & 100 & 78 & 18 & 0 & 4 \\
\hline 7 & 8.2 & 2815 & 255 & 255 & 100 & 53 & 42 & 0 & 5 \\
\hline 8 & 8.4 & 1480 & 149 & 163 & 110 & 20 & 60 & 0 & 20 \\
\hline 9 & 7.5 & $>3999$ & 133 & 137 & 103 & 73 & 22 & 1 & 4 \\
\hline 10 & 7.8 & 3990 & 208 & 212 & 102 & 65 & 31 & 0 & 4 \\
\hline
\end{tabular}

Single analyses for each site

$*$ F/A: filtered $0.45 \mu \mathrm{m}$ and acidified to $1 \%$ nitric acid. 
Table 3: Correlation between arsenic species determined by the SPE and HPLC-ICPMS methods $(\mathrm{P}<0.01)$ using Spearman correlation for $15 \mathrm{DGC}$ and $10 \mathrm{LU}$ sites.

\begin{tabular}{|l|c|c|c|c|c|}
\hline & $\mathrm{As}^{\mathrm{III}}$ & $\mathrm{As}^{\mathrm{V}}$ & $\mathrm{DMA}$ & $\mathrm{MA}$ & $\begin{array}{c}\text { Sum Species } \\
\text { SPE vs HPLC }\end{array}$ \\
\hline DGC, UK & 0.999 & 0.980 & 0.999 & 0.989 & 0.999 \\
\hline $\begin{array}{l}\text { Ing. Luiggi, } \\
\text { Argentina }\end{array}$ & 0.974 & 0.965 & $\mathrm{n} / \mathrm{a}$ & 0.986 & 0.993 \\
\hline All sites & 0.999 & 0.982 & 0.999 & 0.991 & 0.999 \\
\hline
\end{tabular}

